\title{
Passing along an increase in ad costs
}

\author{
Hal Varian ${ }^{*}$
}

Consider a situation where a firm faces a downward sloping demand curve for its product and purchases advertising services from a marketing services provider. The firm chooses both the product price and the amount of advertising services so as to maximize profit.

One day the marketing provider increases the cost of its services. Can the product firm pass along some or all of this price increase by raising the product price?

Intuitively, the answer is "no". If the product firm was already choosing the profit-maximizing price, it cannot generate more profit by increasing its price. In this talk I explore this intuition using a simple model.

The basic framework is a standard discrete choice model where consumer willingness to pay is distributed across the population. If we draw a random sample of size $\mathrm{n}$ from the population, the fraction of consumers willing to buy at price $\mathrm{p}$ is $(1-\mathrm{F}(\mathrm{p}))$, the expected number of consumers willing to buy at this price is $(1-F(p)$ $n$, and the expected revenue is $r(p) n=p(1-F(p)) n$. For convenience, we assume marginal cost is zero, so this expression also denotes profit.

We have assumed a random sample from the population but the sample could be stratified by things like age, gender, purchase history, viewed ad, and so on.

The cost of an audience of size $n$ is $m(n)$, which we take to be an increasing convex function. Combining revenue and cost we have the profit-maximization problem

$$
\max _{\mathrm{p}, \mathrm{n}} \mathrm{r}(\mathrm{p}) \mathrm{n}-\mathrm{m}(\mathrm{n})
$$

By inspection the overall profit maximization problem is separable into two sub problems: first choose the price to maximize profit per audience member, then choose audience size to maximize overall profit, give the chosen price.

Note that when the cost of advertising increases, the amount of advertising decreases, as one would expect but the intuition stated above is true: an increase in the cost of audience acquisition, $\mathrm{m}(\mathrm{n})$, cannot be passed along to product price since product price is already set at the optimal level.

In the paper I have extended this result to cases where the audience provider or the product provider are in competitive markets. In the latter case, there may be multiple equilibria, and pass along may or may not be possible.

My conclusion is that one should be careful about casual claims that firms can pass along increases in ad costs, as it is not true in general.

Accepted: 9 November 2021

Published online: 17 November 2021

\section{Publisher's Note}

Springer Nature remains neutral with regard to jurisdictional claims in published maps and institutional affiliations.

\footnotetext{
*Correspondence: hal@ischool.berkeley.edu
}

Google LLC, Mountain View, CA, USA original author(s) and the source, provide a link to the Creative Commons licence, and indicate if changes were made. The images or other third party material in this article are included in the article's Creative Commons licence, unless indicated otherwise in a credit line to the material. If material is not included in the article's Creative Commons licence and your intended use is not permitted by statutory regulation or exceeds the permitted use, you will need to obtain permission directly from the copyright holder. To view a copy of this licence, visit http://creativecommons.org/licenses/by/4.0/. 